\title{
Implementation of the ERP Concept in a Process-Managed Commercial Company: A Case Study
}

\author{
Petr Sodomka ${ }^{1}$, Hana Klčová ${ }^{1}$ and Jiří Kříž ${ }^{1}$ \\ ${ }^{1}$ Center for inVestigations into Information Systems (CVIS), Department of Informatics \\ Faculty of Business and Management (FBM) \\ Brno University of Technology (BUT) \\ Kolejní, Brno Czech Republic
}

Correspondence should be addressed to: Hana Klčová; hana.klcova@cvis.cz

Received date: 7 March 2014; Accepted date: 3 July 2014; Published date: 31 December 2014

Academic Editor: Dimitra Pappa

Copyright @ C 2014. Petr Sodomka, Hana Klčová and Jiří Kříž . Distributed under Creative Commons CC-BY 3.0

\begin{abstract}
The case study discusses the deployment and use of the ERP system in the company SIKO Koupelny, which owns the largest specialized network of stores in the field of bathroom equipment in the Czech Republic. The study describes how this prestigious commercial enterprise coped with the selection of the ERP system and with the implementation project, and what benefits it gained from its use. The study also includes the experience with the application of the so-called ERP concept - the process-oriented strategy. In its realization, the organization itself has actively used the ERP system and cooperated with its supplier to improve processes and increase their performance.
\end{abstract}

Keywords: Information system; ERP system; ERP concept; strategic management; process management; implementation project

\section{Introduction}

The company was founded in 1991 in the South Bohemian town of Čimelice as a family business selling Rakovník wall and floor tiles. Over time, the company has evolved into its current form of a processmanaged company with 435 permanent employees, and reached the revenue of CZK 2.3 billion (in 2012). Since 2005, the number of items supplied has doubled to currently more than 53,000 . The company serves approximately 2,500 domestic wholesale customers mainly from the ranks of construction and retail companies.

The company seat and management have remained in Čimelice, where a central warehouse and a logistic centre are also located. The company purchases goods 
from the whole world, for example from China, Turkey, Italy or Spain. To maintain high flexibility, it does not bind itself in long-term contracts with its suppliers.

The company owns 19 captive companies; 12 additional companies transact business on the basis of a licence agreement and use the business name SIKO. Almost all branches are engaged in both wholesale and retail trade at the same time. The goal of the company is to have branches in all regional towns, and to further expand its activities to the east, especially to Slovakia. The first captive branch in Slovakia opened in 2010; in 2012, SIKO Koupelny already had eight sales offices in seven towns of Slovakia.

\section{Research Methodology}

Every year, the Center for inVestigations into Information Systems conducts research of the Czech ERP market, the integral part of which is the processing of case studies in the form of qualitative enquiry and the technique of a projection interview with the staff responsible for investments in the IS/ICT in the relevant organization. In 2005-2013, the authors conducted more than 130 such case studies in manufacturing, trading and service enterprises in the Czech and Slovak Republics.

The authors used the following literary sources as the theoretical foundation for the application of the research methodology: Gill, Johnson, 1991, and Pavlica, 2000. For processing the case studies, they then used the information from the book Case Study Research (Yin, 2003). The theoretical foundation for the realization and evaluation of implementation projects is based on extensive practical experience of the Center for inVestigations into Information Systems, and on the long-term study of the following professional sources: Voř́šek, 1997, Davenport, 1998, Molnár, 2001, Basl, 2002, Olson, 2003, Olson, Chae, Sheu, 2005, Smejkal, Rais, 2006, Laudon, Laudon, 2006, Schwalbe, 2007, Pour, Gála, Šedivá, 2009.
The authors used and studied theoretical knowledge concerning implementation projects also from the studies of analytical companies focused on the global and Czech markets, such as Deloitte Consulting, 2000, Accenture, 2001, Hestermann, Anderson, Pang (Gartner), 2009.

When processing the case study, the authors also relied on publications dealing with process management, management of business information science, knowledge management and corporate performance management from the following authors: Kirchmer, Scheer, 2004, Řepa, 2011, Řepa, 2012, Pour, 2008, Buřita, Hagara, Ondryhal, 2012, Chvátalová, Hřebíček, 2012, Kocmanová, Hřebíček et al., 2013.

\section{Implementation of a new ERP project}

\section{Strategic background and definition of key requirements}

Changing the family business to the process-managed company, necessitated by the dynamic growth in all areas of the company activities, also entailed a change in customer orientation. At the beginning, a target segment was represented by customers buying cheap products. Over time, however, the company switched to the customers with a higher potential for purchasing better quality and more expensive goods. The management also reformulated the mission, which has changed from "No one so well for less" to "Shops full of inspiration".

Jan Dvořák, Chairman of the Board of Directors of SIKO Koupelny, said about the strategic objectives: "We focused on the presentation of comprehensive solutions of bathrooms, and therefore restricted the proportion of truly cheap goods to a minimum. That is why we build large showrooms, which occupy a minimum area of 1,000 m2. We make effort to always have - in our showrooms - the goods which are different from the competition and which no one else has; we also strive to offer the widest portfolio of products".

"Due to the ever increasing demands of customers, our company must profile itself not only as a seller, but also as a consultant. 
We therefore put emphasis on training of our staff, so that they can professionally advise our customers," concludes Jan Dvořák.

One of the main competitive advantages of the company is that the customer can get the goods as soon as he/she chooses them. The company can cover the demand for high-turnover goods in the branches from the central warehouse. This represents the whole quarter of all items recorded in the information system. The rest mainly consists of expensive goods, which are supplied by order and imported from abroad. When doing this, the order is issued using the information system on the basis of historical data. A critical point for stock management and the whole logistics lies in linking together the following two conflicting requirements:

To have the goods in stock and maintain a competitive advantage;

To effectively manage the stock from the costs point of view.

The information system should be the most appropriate tool for combining these two requirements, so that the desired products are available in sufficient quantities, while the stock management is not burdened by unsalable goods. It cannot be therefore forgotten that the number of items keep increasing every month by the current assortment being extended. By this, the amount of unsold goods also increases. It is not easy to sell the goods fast; it is prevented - inter alia - also by the inability to combine some of their types, such as wall and floor tiles. There is therefore an essential difference between the exclusion of the goods from the offer and their physical removal. Mainly for this reason, inventory management is one of the most complex processes across the organization.

Before the implementation of the comprehensive ERP system, SIKO Koupelny managed its operations by means of several separate applications, which covered warehouse management, finance, accounting and payroll. The company expansion, changing requirements to its management and problems to integrate the processes clearly led to the decision to change the management of company information.

Jan Dvořák comments on the key decisions about the information system: "We tried to make a clear idea about our business plans. We considered whether to continue the expansion also outside the Czech Republic, or whether to stop at the border. We came to the conclusion that in addition to our extensive growth, we must also ensure intensive development of the company, especially in the context of increased competition affected by the accession of the CR to the EU."

"We also wanted to learn from the mistakes of other companies, which - by saving on the information system - later ran into trouble. We therefore chose to select the world advanced ERP solution that would constitute a core of the company information system. The decision to buy a big world system was also the most difficult for our company, as we were aware that it would be necessary to address many serious problems," adds Jan Dvořák.

\section{The main aspects of implementation}

The main criteria for selecting an information system included the meeting of the company needs and the potential of the information system. The costs of the project implementation and system operation represented only the second decision-making criterion.

The systems SAP Business All-in-One (then called mySAP All-in-One) and Microsoft Dynamics AX (formerly Microsoft Axapta) got into the final short list of the tender. The decision to choose an SAP-based solution was finally made by considering a number of references and system integrators in the $\mathrm{CR}$, and the robustness of the system and its potential, which will in no way limit the company's growth. Axapta, however, still received a very positive rating by the company management, especially in terms of its user-friendliness. 
But at the time of the system selection Axapta did not have a sufficient number of references, and therefore ultimately did not succeed.

At the beginning, the managers of the company did not expect that they would choose an SAP information system; it appeared to them to be too expensive and robust. But they wanted a system that would comprise the greatest potential for possible development. They therefore decided to familiarize themselves with SAP - among other solutions. In doing so, they were aware that if they chose SAP, they would not be able to fully use its functionality right from the beginning, which was eventually confirmed.

Table 1: The main information on the implementation project of the SAP Business All-inOne ERP system in SIKO Koupelny (prepared by ourselves)

\begin{tabular}{|c|c|}
\hline ERP system & SAP Business All-in-One \\
\hline Implementation partner & Mibcon \\
\hline Period of implementation & 8 months (May 2004 - December 2004) \\
\hline Last upgrade & 2011 \\
\hline Number and type of users & 160 named users \\
\hline Server operation system & MS Windows Server \\
\hline Database platform & MS SQL Server \\
\hline Architecture & $\begin{array}{l}\text { Two-layer client/server, using the technology of the thick client; } \\
\text { server is implemented in the form of hosting, branches are } \\
\text { connected by VPN, connectivity is provided by external provider }\end{array}$ \\
\hline Processes covered by ERP system & $\begin{array}{c}\text { Economics; buying, selling and internal logistics; human resources } \\
\text { management }\end{array}$ \\
\hline Project benefits & $\begin{array}{l}\text { Standardization of business processes according to SAP; strong } \\
\text { support of controlling, finance control and sales; availability of } \\
\text { accurate information for all users; unified information system } \\
\text { environment }\end{array}$ \\
\hline
\end{tabular}

The SAP-based solution from the Mibcon company was finally selected for two reasons: because of the speed and cost of implementation. There was no need for interfaces to other systems, such as the cash register system, which was proposed in other SAP versions. Company managers wanted to make retail sales online directly from the system according to user requirements. The main requirement was to keep the information about the order and its development in one document. Almost $70 \%$ of orders are handled by the system, with some items in stock and others being ordered.
Miloslav Bašta, who led the IT department at the time of selecting and implementing the system, further stated on the topic of adapting the SAP system: "In other areas we did not try to adapt the system too much to our processes. We tested standard SAP processes, and then their parameterization followed. Not even one of the originally proposed 70 change requests that would require the customization of the system was eventually materialized. We standardized our key processes according to SAP and the people in the organization were forced to adapt. Our later experience has shown that this was the right way to go." 


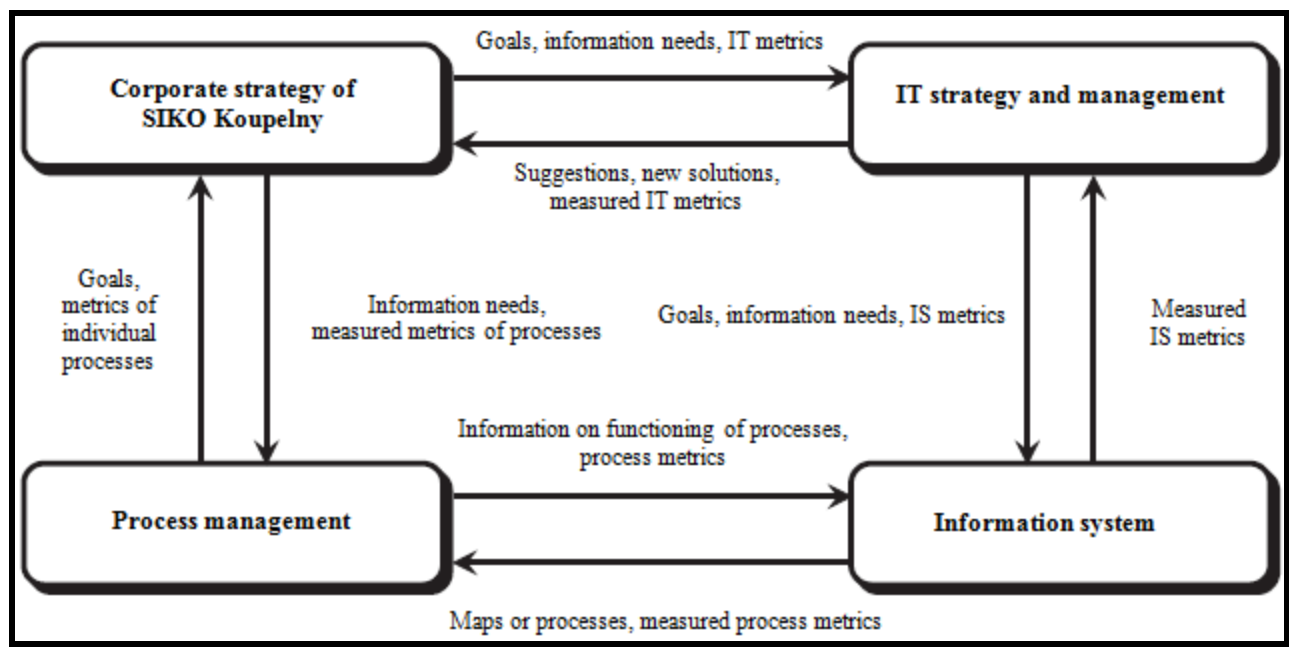

Figure 1: Information system as part of management in SIKO Koupelny (prepared by ourselves)

\section{Motivation system}

Employees involved with the implementation were already taking part in choosing the system. After selecting the solution, an implementation team was established, the core of which consisted of employees - key users responsible for individual processes. The principle of a positive approach was established, and the implementation team became its bearer. It was the only way how to handle a demanding process of implementing and putting into operation a robust system of the SAP brand.

Managers tried to mentally prepare their colleagues to the fact that the project would bring a radical change in the wellestablished practices, which would initially mean a lot of work. The actual motivation of people took place in two steps. First of all, it was necessary to excite everybody by emphasizing the benefits of the IT project for their own work and for the company business. The second step concerned the level of financial remuneration of people involved in the project according to their merits with a focus on key users. Remunerations were promised in advance and the employees informed that they would be paid depending on how the individuals get actively involved in the implementation of the project. The managers regarded this type of motivation as very effective, because in this way people could materialize their efforts put into the project into something they needed themselves. In addition to financial incentives, non-financial motivational factors also proved to be positive, such as increased personal qualification and making everyday routine work more effective by means of the new information system.

\section{Benefits in accordance with the goals}

The main benefit consists in fulfilling the defined goals of the project. The management demanded a robust global system with a great potential, and we managed to successfully deploy it. New opportunities appeared that were previously not considered. For example, based on the requirements of key users, the functionality of contacts with customers within the sales support was put into operation.

Another benefit is a unified environment that allows the standardization of processes or enforceability of standardized work of users. An example is managing the process of selling to a non-paying customer by the tool "blocking the order". This tool monitors whether the customer has paid for the order or not. If the customer has not 
paid, the sale does not go through or has to be ordered by a superior staff. The setting of this process in the system has a direct quantifiable effect in reducing the overdue receivables.

Indisputable benefits have been brought about by a rapid response of the system in communication with the customer. The staff in the stores are able to instantly check the availability of desired goods, their quantity and delivery terms. The information system also significantly helps marketing. It makes it possible, for example, to trace the relationships between the displayed goods and their saleability.

And last but not least, the implementation project helped solve problems in controlling and finance management - i.e. in the areas in which SAP is traditionally strong. The company management considers it essential that employees in all sections have the same and correct information at their disposal, according to which they conduct their daily agenda.

\section{Experience from the operation and areas of further development of the system}

SIKO Koupelny continues to develop the SAP system in cooperation with the Mibcon company. "Over the last five years, we have tried to involve also other SAP partners in our projects. Each company has a different level of formalization of their own ways of operation and ways of building their corporate know-how. The level of customer satisfaction is ultimately most dependent on the personalities of consultants who deal with the specific project. We therefore remained loyal to Mibcon. They have quality consultants for retail and logistics, and are also very strong in the area of Business Intelligence," comments on his experience Miloslav Bašta, who is now responsible for controlling in the company.

"All SAP partners whom we have had an opportunity to meet believe in a myth that if their customers could afford to buy SAP, they also have to come to terms with all other costs. So much emphasized customer approach remains a proclamation," does not avoid criticism Miloslav Bašta, and adds: "I also see as problematic the SAP business policy, which - instead of considering the impacts of the economic crises on the customers - increased the prices and exacerbated an already low potential of sales of SAP products in the CR."

Since the beginning, the company has adhered to the strategy of primary deployment of SAP-based applications. The reason is an easy integration, uniform environment and the ownership of licences that contain all that is included in the original set of Business Suite modules. First of all, the company managed to successfully complete the implementation of the Business Intelligence solution on the NetWeaver 7 platform. Benefits of this project mainly lie in ensuring a uniform source of data, and data cleaning and adjustment for subsequent reporting and analyses. Users also appreciate an option of data visualization, variability and making their own reports. The data can be presented through the portal, which makes them accessible to a wide range of staff throughout the company.

At the beginning of 2011, another important part was put into operation: Business Suite - SAP Warehouse Management. In the same year, there was an upgrade to SAP ERP, which includes NetWeaver, an integration and application platform.

\section{Implementation of the ERP concept as a process-oriented strategy}

\section{Theoretical background}

The business information system can be viewed in several ways. The fundamental view, however, leads through the strategic intention of the organization to the requirement to formalize the information, to process the information by the information system and to provide truthful, meaningful outputs. The ability to make a correct decision about which information needs to be automated and which should be kept on paper or in minds of people is one of the main factors supporting the growth of business performance and value 
of the organization. The main basis for these decisions should be a business-wide strategy and subsequently an information strategy. The process-oriented strategy that uses the options of the ERP system and influences the management of internal business processes is referred to as the ERP concept (Sodomka, Klčová, 2010). Its practical implementation then leads to the following:

Improving the flow of information towards the business processes and making the operation of the business as a whole more effective.

Improving the flow of information towards individual management levels of the company;

improving the support of decision-making and optimizing the business processes based on feedback.

Making the ERP system management more effective throughout its life cycle.

The ERP concept can thus help to answer the questions how and with whom to carry out the implementation project, how and what to train the system users, what work habits need to be changed, when to upgrade the application software, etc. For this, it is - of course - necessary that the people responsible for the ERP concept know the processes and the operation of the business as a whole, be able to put requirements on the ERP system and be able to re-evaluate whether these requirements are being met. Then we can say that the ERP system has met the basic requirement - to support the increasing of performance and the value of the company. An example of the systematic building of the ERP concept is the SAP project in SIKO Koupelny.

\section{Practical implementation of the ERP concept}

The management of the company SIKO Koupelny regularly evaluates the management system in terms of its performance. The review of the system takes place at management meetings once every six months. A comprehensive analysis of the status of the management system is carried out once a year. These reviews involve the discussion over a report that summarizes the achieved results of the company and the identified problems that arose in the previous period. The company management then evaluates the management system in terms of its performance and discovered problems. The report on the status of the management system is prepared at least one week prior to the management meeting and then distributed to all members who prepare their comments for the management meeting. The current status (or rather the problems of the management system) is not only discussed at the regular meetings of the company management, but also within branches and specialized departments.

The report on the status of the management system is prepared by the IT manager. His/Her competencies also include the administration of the SAP ERP system. The report is prepared on the basis of the data supplied to the IT manager by other responsible people - owners of business processes. For this purpose, the IT manager organizes meetings once a month with process owners and key users of SAP. There are three owners - managers responsible for sales (logistics), economics, and human resources management. In the team, they are accompanied by their subordinates - other key users who are in charge of individual sub-processes. The process owners in cooperation with key users of the information system evaluate the feedback acquired from SAP and vice versa - reflect into it the necessary changes.

\section{The development of the ERP concept for SAP implementation}

Based on the business-wide strategy, the IT management updated the information strategy document that defined IT tasks for different business areas, so that the options of the newly deployed system can be utilized in the best possible way. However, after a year of the SAP productive 
operation it showed that the key users do not sufficiently fulfil their roles within the ERP concept. Their team was therefore disbanded and a new team established. The purpose of this step was to further develop SAP for it to best support the company growth.

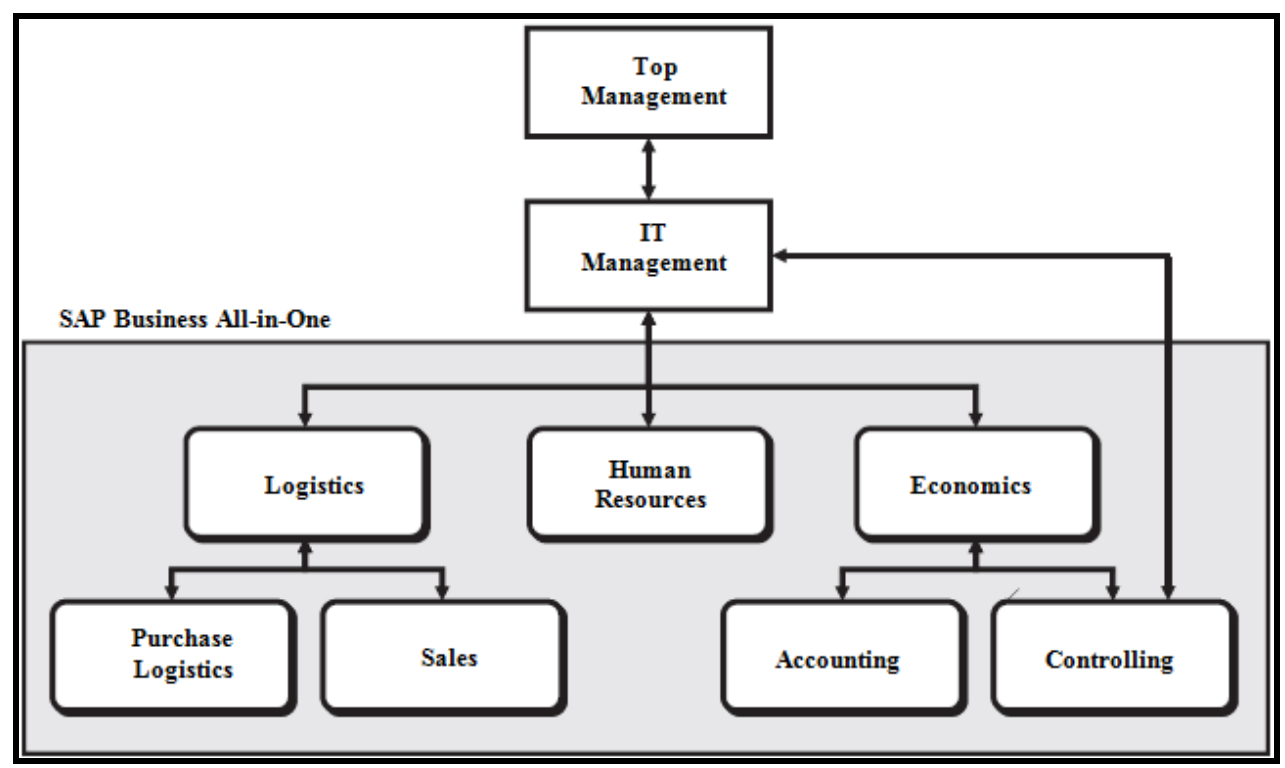

Figure 2: Scheme of ERP concept implementation in SIKO Koupelny (prepared by ourselves)

Implementation of the ERP concept envisages taking over the initiative in the development of the system by key users. It has shown that the continuous innovation of the system with active cooperation of key users is an important incentive to improve their own work, which in turn leads to an improvement of processes and the results of operation of the whole organization.

At the same time, the business process is not the same as the SAP module. Processes extend across the whole system. The IT management task is to give suggestions for each key business process. These suggestions are then confronted with the experience of the owners of processes and key users - there is a controlled conflict of the IT management and the team of users. If it is necessary to solve the arising problems or requirements by a more radical intervention into the information system, then these two teams meet the external partner responsible for the SAP project - i.e. the consultants of the system integrator.

\section{Conclusion}

\section{Experience and suggestions}

- The management of the organization is responsible for consulting relevant steps of the top decision-making with the IT department.

- It is necessary to respect the rule that new processes cannot be created and existing processes modified without a direct link to the information system.

- It has turned out that during the implementation of the information system it is suitable to set up the processes more generally and then to fine-tune them according to the experience.

- Within the consultations of the teams, it is necessary to ensure that key users are actively involved in updating the process maps so that they match the reality. 
- Meetings at different levels of management became an information source for the continuous development of the system (e.g. in the area of product management, or a business-wide meeting with the heads of branches).

- The gradual development of the system is necessary to maintain the motivation of people to improve their own work and increase the knowledge basis of the organization. Once this process is stopped, it is very difficult to reopen it. It is also necessary to take into account the fact that people must first learn to work with the system.

\section{Existing benefits from practical implementation of ERP concept}

- Strengthening the management of the company as a whole through a holistic approach.

- Carrying out system changes in the creation and control of documents and strengthening control mechanisms on the basis of reports produced by the information system.

- Linking the process documentation (process maps and guidelines), SAP manuals (procedures for end users, how to sell, how to dispatch goods, etc.) and company documentation (in-house standards, organizational structures, organizational guidelines, etc.); this helps especially middle management, e.g. by improving information flows for branch managers.

- Separation of the purchasing process and its centralization including all branches. SAP provided a powerful tool for centralizing the purchasing, thus enabling responsible staff to focus exclusively on this important work.

\section{References}

1. Accenture. (2001) Hodnota podnikových informačních systémů $\mathrm{V}$ České republice. Interní studie společnosti Accenture

2. Basl, J. (2002) Podnikové informační systémy. Grada Publishing, Praha

3. Buřita, L.; Hagara, L.; Ondryhal, V. (2012) Knowledge Systems for User Applications and Education. In 7th IEEE International Conference on Knowledge, Information and Creativity Support Systems (KICSS 2012). Melbourne, Australia, Proceedings, pp. 1-6

4. Chvátalová, Z.; Hřebíček, J. (2012) Modelling of economic phenomena and dependences for corporate sustainable performance. In I. J. Ramík, D. Stavarek. 30th International Conference on Mathematical Methods in Economics. Karvina, Silesian Univ Opava, Sch Business Adm Karvina, pp. 350-354

5. Davenport, T. H. (1998) Putting the Enterprise into Enterprise Systém. Harvard Business Review. July-August, 1998, no. 3, pp. 121-131

6. Delloitte Consulting (2000). ERP's Second Wave - A Global Research Report.

7. Gill, J., Johnson, P. (1991) Research Methods for Managers. P. Chapman Publishing, London

8. Hestermann, C.; Anderson, R. P.; Pang, C. (2009) Magic Quadrant for Midmarket and Tier 2-Oriented ERP for ProductCentric Companies. Gartner RAS Core Research Note G00163386

9. Kirchmer, M.; Scheer, A. W. (2004) Business Process Automation - Combining Best and Next Practices. In A. W. Scheer, et al. Business Process Automation: Aris in Practice. New York: Springer-Verlag Berlin Heidelberg, pp. 1-16

10. Kocmanová A.; Hřebíček, J.; Dočekalová, M.; Hodinka, M.; Hornungová, J.; Chvátalová, Z.; Kubálek, T.; Popelka, 0.; Šimberová, I.; Topolová, I.; Trenz, O. (2013) 
Měření podnikové výkonnosti. Littera, Brno.

11. Laudon, K. C.; Laudon, J. P. (2006) Management Information Systems (9th edition). Pearson Prentice Hall, New Jersey

12. Molnár, Z. (2001) Efektivnost informačních systémů. Grada Publishing, Praha

13. Olson, D. L. (2003) Managerial issues of ERP systems. McGraw Hill/Irwin, New York

14. Olson, D. L.; Chae, B.; Sheu, C. (2005) Issues in multinational ERP implementation. International Journal of Services and Operations Management, vol. 1, no. 1, pp. 7-21

15. Pavlica, K. et al. (2000) Sociální výzkum, podnik a management. Ekopress, Praha

16. Pour, J. (2008) Performance and effects of corporate informatics. In IDIMT-2008: Managing the unmanageable. Jindrichuv Hradec: 16th Conference on Interdisciplinary Information

17. Management Talks. Publisher: Universitatsverlag Rudolf Koglstr, Linz, Austria, Book Series, Schriftenreihe Informatik, vol. 25, pp. 53-61
18. Pour, J.; Gála, L.; Šedivá, Z. (2009) Podniková informatika (2. přepracované a aktualizované vydání). Grada Publishing, Praha

19. Ǩepa, V. (2011) Building the Processmanaged Organization by Means of Services. Journal of Systems Integration, vol. 2, no. 2, pp. 11-16

20. Řepa, V. (2012) Evaluation of the BPMN According to the Requirements of the Enterprise Architecture Methodology. Journal of Systems Integration, vol. 3, no. 2, pp. 39-50

21. Schwalbe, K. (2007) Řízení projektů v IT, kompletní průvodce. Computer Press, Brno.

22. Smejkal, V.; Rais, K. (2006) Řízení rizik ve firmách a jiných organizacích. Grada Publishing, Praha

23. Sodomka, P., Klčová, H. (2010) Informační systémy v podnikové praxi. 2 . aktualizované a rozšířené vydání. Computer Press, Brno.

24. Voříšek, J. (1997) Strategické řízení informačního systému a systémová integrace . Management Press, Praha

25. Yin, R. K. (2003) Case Study Research: Design and Methods (3rd edition). Thousand Oaks, Sage Pub, Inc. 